\title{
Signal transduction via integrin adhesion complexes
}

DOI:

10.1016/j.ceb.2018.08.004

Document Version

Accepted author manuscript

Link to publication record in Manchester Research Explorer

\section{Citation for published version (APA):}

Humphries, J., Chastney, M., Askari, J., \& Humphries, M. J. (2019). Signal transduction via integrin adhesion complexes. Current opinion in cell biology, 56, 14-21. https://doi.org/10.1016/j.ceb.2018.08.004

\section{Published in:}

Current opinion in cell biology

\section{Citing this paper}

Please note that where the full-text provided on Manchester Research Explorer is the Author Accepted Manuscript or Proof version this may differ from the final Published version. If citing, it is advised that you check and use the publisher's definitive version.

\section{General rights}

Copyright and moral rights for the publications made accessible in the Research Explorer are retained by the authors and/or other copyright owners and it is a condition of accessing publications that users recognise and abide by the legal requirements associated with these rights.

\section{Takedown policy}

If you believe that this document breaches copyright please refer to the University of Manchester's Takedown Procedures [http://man.ac.uk/04Y6Bo] or contact uml.scholarlycommunications@manchester.ac.uk providing relevant details, so we can investigate your claim.

\section{OPEN ACCESS}




\title{
Signal transduction via integrin adhesion complexes
}

Jonathan D. Humphries^, Megan R. Chastney^, Janet A. Askari^ and Martin J. Humphries*

Wellcome Trust Centre for Cell-Matrix Research, Faculty of Biology, Medicine \& Health, Manchester Academic Health Science Centre, University of Manchester, Manchester, M13 9PT, UK

${ }^{*}$ Correspondence should be addressed to $\mathrm{MJH}$

Phone: +44 (0) 161 2755071; Fax: +44 (0) 161 2755082; Email:

martin.humphries@manchester.ac.uk

${ }^{\wedge}$ These authors contributed equally

The authors declare no conflict of interest

\begin{abstract}
Integrin adhesion complexes (IACS) have evolved over millions of years to integrate metazoan cells physically with their microenvironment. It is presumed that the simultaneous interaction of thousands of integrin receptors to binding sites in anisotropic extracellular matrix (ECM) networks enables cells to assemble a topological description of the chemical and mechanical properties of their surroundings. This information is then converted into intracellular signals that influence cell positioning, differentiation and growth, but may also influence other fundamental processes, such as protein synthesis and energy regulation. In this way, changes in the microenvironment can influence all aspects of cell phenotype. Current concepts envisage cell fate decisions being controlled by the integrated signalling output of myriad receptor clusters, but the mechanisms are not understood. Analyses of the adhesome, the complement of proteins attracted to the vicinity of IACs, are now providing insights into some of the primordial links connecting these processes. This article reviews recent advances in our understanding of the composition of IACs, the mechanisms used to transduce signals through these junctions, and the links between IACs and cell phenotype.
\end{abstract}

\section{IAC components}

Cells adherent to ECM proteins assemble a range of IACs that are focally distributed $[1,2]$. Detailed functional and morphological analyses have defined several major forms of IAC, including focal complexes, focal adhesions and fibrillar adhesions [2]. Each type of IAC is formed sequentially and disrupted as cells migrate and, based on immunofluorescence analyses, each has a distinct composition. Most recently, a new class of adhesion, which contains high levels of integrin $\beta 5$, clathrin and endocytic adaptors, has been identified by a range of laboratories and variously termed flat 
clathrin lattices, clathrin plaques or reticular adhesions [3-6]. The extent to which these reports describe the same type of adhesion complex is currently unclear. All IACs are connected to the actomyosin cytoskeleton via adaptor proteins such as talin and vinculin (except reticular adhesions [6]), but they also serve as hubs that link integrin-containing plasma membrane regions to the cytoplasmic signalling network.

IACs are located at the membranous junction between ECM-bound, plasma membrane-intercalated integrins and intracellular, actin-based cytoskeletal filaments. Isolation of such a structure away from all adjacent cellular material is currently not possible, but in the last decade techniques have been developed to purify ventral IACs from cells in 2D culture, together with material that is found in close apposition to the junction [7-9]. Since the function of IACs is to convert spatiotemporal information about the extracellular environment into signals with wide-ranging consequences, the composition of these purified IACs, and their associated material, is highly relevant.

Although a range of cell types has been investigated, most IAC preparations have been isolated from cells attached a fibronectin substrate. Compilation of seven of these datasets led to the definition of a fibronectin-induced 'meta adhesome' of over 2400 proteins, which was further refined to 60 core proteins most frequently identified in IACs, termed the 'consensus adhesome' [10]. The consensus adhesome is likely to represent the core cell adhesion machinery, centred round potential axes that link integrins to actin (e.g. ILK-PINCH-parvin-kindlin, FAK-paxillin, talin-vinculin and a-actinin-zyxin-VASP; Figure 1). This core connection network has recently been integrated with a 'literature-curated adhesome', generated in silico by Geiger and colleagues [11,12], and has proven valuable for filtering large datasets and identifying potential candidates for follow-up experimentation [13-21]. A recent meta analysis suggests nearly $20 \%$ of the human kinome is found in the adhesome, supporting the view that this region of the cell is a general signalling hub [22].

Since publication of the meta adhesome, IAC preparations have been generated from other cell types, such as endothelial cells [23], but in the future proteomic analysis of IACs isolated from a wider range of cell types in various cellular contexts (e.g. different ligands, in 3D culture, or in vivo) will undoubtedly broaden our understanding of adhesome composition and regulation. Similarly, current IAC preparations are isolated from thousands of cells, and therefore comprise a range of different types of IAC, found in different subcellular locations. Future improvements in mass spectrometric sensitivity will enable more focused analyses of the composition of IACs in space and time. In recent years, new techniques for IAC analysis have been developed, including the use of mass spectrometry in conjunction with the proximity-dependent biotinylation technique, BiolD [20]. By using this method with paxillin and kindlin baits, a number of well-established adhesome components were identified, but in addition several new associations were revealed, including Kank2 (for paxillin) and liprin- $\beta$ ?for kindlin). In parallel studies, another Kank family member, Kank1, was localised to the periphery of mature IACs through its ability to bind talin. At these sites, Kank1 coordinated the formation of cortical microtubule stabilisation complexes (containing ELKS, liprins, KIF21A, LL5 $\beta$ and 
CLASPs), which in turn led to the destabilisation of IACs [24,25]. Thus, although marginally failing to meet the criteria for inclusion in the original consensus network [10], Kank proteins now appear central to integrin regulation and should be considered core adhesome components. Additional key functional interactions within the consensus adhesome that have been elucidated recently include a role for kindlin-2 dimerisation in integrin activation and clustering [26], direct kindlin-actin binding [27], and a role for the kindlin-paxillin axis in activation of Rac1 and recruitment of Arp2/3 to early IACs [28].

The coordinated assembly and disassembly of IACs must be tightly regulated for effective cell adhesion and migration. A highly multiplexed, high resolution imaging approach revealed that as IACs were assembled, molecular noise was reduced, suggesting that despite the large number, and extensive binding capabilities, of adhesome components, IAC assembly is tightly regulated [29]. Further studies have identified novel roles for well-known adhesome components in the maintenance of integrin activation during integrin endocytic recycling prior to IAC assembly. FAK, talin, and PIPKI $\gamma 2$ were shown to associate with endocytosed integrins, maintaining their active state, and priming them for rapid IAC formation at the leading edge of migrating cells [30].

\section{Mechanotransduction via IACs}

A major challenge is to elucidate the mechanisms whereby information is transduced through IACs. It is now firmly established that the ability of cells to sense force, generated externally via the ECM or internally by actomyosin-based contractility, and convert that information into biochemical signals, plays a key role in differentiation and proliferation [31,32]. Altered cell and tissue stiffness modifies transcriptional programming [33], thereby affecting lineage decision-making, and is also associated with diseases such as cancer and fibrosis [34,35]. Our understanding of mechanosensing has increased substantially in recent years and has been reviewed in depth [36-38]. Here, we focus on recent conceptual and mechanistic advances.

Integrin-actin connection via a molecular clutch

Force sensing is transmitted by integrin receptors and their associated adhesion signalling complexes via a molecular clutch, whereby cell-ECM bonds dynamically engage and disengage with the cytoskeleton [39]. By using nanopatterned substrates of defined ligand separation distances, the clutch was shown to function by recruitment of additional integrins to allow the distribution of force over multiple connections [40]. This model demonstrated how low ligand spacing promotes IAC formation on soft substrates, but leads to collapse on stiff substrates. In this way, both ECM rigidity and molecular spacing determine an optimal threshold for IAC formation to coordinate with downstream signalling [40]. Additionally, the molecular clutch model has been shown to be relevant to ligand mobility changes (surface viscosity) [41] and membrane tension [42]. Using nanopatterning to create aligned 
ECM resulted in spatially constrained IAC orientation, presumably via spatial restriction of the organisation of the molecular clutches, that resulted in anisotropic traction forces and facilitated cell orientation and directional migration [43].

\section{Force-dependent changes in composition}

Analysis of force-dependent changes in the consensus adhesome revealed that the majority of components were reduced or lost when actomyosin contractility was inhibited [44]. The turnover of talin and vinculin, but not FAK and paxillin, was increased by extracellular stiffness [45], suggesting that these proteins are specifically responsible for mechanotransduction. Moreover, while phosphorylation of paxillin and FAK was not responsible for force-sensitive changes in vinculin dynamics, it was required for subsequent Rac1-dependent signalling processes [45]. These data are consistent with studies that demonstrated migration and proliferation induced by FAK- and Src-dependent phosphorylation occurs independently of IAC composition [21] and demonstrate possible segregation of signalling and mechanosensing functional modules within IACs.

Further analysis of the links between composition, organisation, turnover and signalling at IACs may be complicated by their molecular heterogeneity and differential response to force modulation [46]. For example, tracking the Rhoassociated kinase (ROCK)-induced changes of IAC proteins using four-colour live cell imaging of zyxin, FAK, vinculin and paxillin revealed an unexpectedly diverse pattern of responses, with the identity of the strongest responder varying between individual IACs [47]. Similarly, the nanoscale organisation of IAC components such as vinculin, paxillin and talin underwent a non-random reorganisation upon myosin inhibition suggesting force-dependent regulation of IAC organisation [48]. Furthermore, while genetic ablation of myosin II in Drosophila embryonic muscles did not cause loss of IACs, the stoichiometry of adhesion sites did depend on contractility, as IAC components were differentially affected by different alterations to muscle contraction [49]. Taken together, all of these findings argue that force might produce rearrangements of proteins within IACs without effecting major changes in composition.

\section{Relay mechanisms}

Mechanotransduction can take several forms, including activation of ion channels, use of catch and slip bonds, and force-induced conformational changes in sensory proteins that lead to the exposure of cryptic binding sites for other proteins. Evidence is accumulating that all of these mechanisms contribute to signal relaying via IACs.

Catch bond behaviour has been demonstrated previously for integrins [50], and now through the use of single molecule optical trapping, vinculin has been shown to form a polarised, force-dependent catch bond with actin [51]. Modelling suggests that the directionality of the vinculin-actin catch bond may have long-range effects on the actin cytoskeleton relevant to migration [51]. Albeit through a different mechanism, 
the application of fluorescence polarisation microscopy to analysis of GFP-tagged integrins has demonstrated a role for directional actin retrograde flow in receptor alignment in IACs [52,53]. Modelling also suggests that a combination of adaptor binding and cytoskeletal force application is required for integrin extension and activation [54].

There are several classes of force-sensitive ion channels, but the Piezo family appears to be functionally relevant for adhesion-related signalling (in addition to its canonical roles in touch sensing and proprioception). Through the use of atomic force microscopy, an ECM dependence to the activation of Piezo1 has been demonstrated [55], calcium flickers generated by Piezo1 have been linked directly to actomyosin-based traction force (https://www.biorxiv.org/content/early/2018/04/03/294611), and activation of Piezo1 in epithelial sheets shown to induce cell division via calcium-dependent activation of the MAPK pathway [56]. L-type calcium channel activity is also regulated by integrin activity and results in maturation of filopodia-associated complexes to IACs [57].

Substantial evidence has accumulated to indicate key roles in mechanotransduction for talin, vinculin and p130Cas [58-63]. In recent years, new tension sensors have been developed for talin and used to probe the role of different regions of the molecule in mechanosensing and IAC formation [64,65]. Tension on talin was higher in peripheral IACs than central IACs, a phenomenon that required the talin actinbinding site 3 (ABS3), while tension sensing on soft versus stiff substrates was mediated by the ABS2 site in conjunction with vinculin [64]. These findings argue for spatial differences in the organisation of IACs. Combined structural and biophysical analyses have now elucidated the conformational changes that take place in vinculin during activation [66].

It is established that the Hippo pathway effectors YAP and TAZ drive transcriptional programmes in response to mechanosensing [31]. Force has now been shown to trigger YAP nuclear entry via a relay involving cortical actin, nucleus-associated cytoskeleton, nuclear membrane flattening and nuclear pore opening [67,68]. As might be predicted, direct roles for core IAC adhesome components such as FAK, kindlin and $\beta$-PIX are now being uncovered [69-71]. Intriguingly, there is growing evidence that many adhesome components shuttle between the cytoplasm and nucleus (reviewed in [22]). When combined with recent interest in the role of nuclear actin in controlling DNA repair [72,73], it is likely that analyses of the structural anatomy and functional importance of the nuclear adhesome will become a major focus.

\section{Distal consequences of signalling via IACs}

Signalling via IACs controls a wide range of cellular functions, including migration, proliferation and differentiation. Ontological analysis of the adhesome, however, 
suggests connections to other cell fate decisions [74]. Here, we review recent advances in our understanding of one established and one novel functional link.

Cell cycle

2018 marks the 50-year anniversary of the confirmation of anchorage-dependent growth and the finding that suspension of normal cells results in cell cycle arrest prior to DNA replication [75]. Subsequent research has identified key signals that link adhesion to the G1 checkpoint [76] and led to the concept of anchorage-dependent survival, or anoikis [77], but despite the major changes in shape that take place during division, other connections between the cell cycle engine and IACs have not been made.

CDK1, the master controller of the cell cycle, primarily pairs with cyclins A2 (outside of mitosis) and B1 (for mitosis) and drives complex morphological programs through phosphorylation of more than a hundred targets [78,79]. These targets include a number of cytoskeletal/adhesion proteins and recent phosphoproteomic analysis of IACs suggested the existence of many more [80]. Inhibition of CDK1 perturbed IACs in interphase cells, implying a role for the enzyme in promoting adhesion when paired with cyclin A2 [81]. Analysis in synchronised cells demonstrated that the loss of IACs prior to mitosis begins in early G2, well before cell rounding [81], and consistent with changes in traction force $[82,83]$. The trigger for this decrease was Wee1-dependent phosphorylation and inhibition of CDK1 activity, which was itself induced by cyclin B1 expression. Thus, a ubiquitous feature of the cell cycle provides a primordial connection between the cell cycle and adhesion. This finding also suggests that there may be links between adhesion and cell cycle checkpoints other than that in G1. In this context, ECM stiffness is an environmental cue that promotes mutant p53 stabilisation via mevalonate-RhoA-mediated mechanosignalling [84]. Furthermore, over-expression of $\beta 1$ integrin correlated with stabilisation of RAD51, which is a key component of the homology-directed DNA repair pathway, by preventing its ubiquitination by RING1 and subsequent degradation, thus increasing cell survival [85]. Taken together, these findings might imply functional links between IACs and the nucleus, and recent evidence suggests nuclear decoupling in response to rapid changes in mechanical loading (https://www.biorxiv.org/content/early/2018/05/09/317404) and evidence of nuclear envelope rupture during confined migration [86].

Most cells round at mitosis, having remodelled or lost their IACs, but do not detach. Since frustrated rounding leads to aberrant division, this also implies cell cycledependent regulation of IACs. Although most IAC components are lost during mitotic rounding, integrins remain in place and mediate adhesion to the substrate via retraction fibres [87] and a new type of adhesion complex that has been termed reticular adhesions (https://www.biorxiv.org/content/early/2017/12/14/234237). These modified IACs provide a template for daughter cell re-spreading following mitotic exit, which may equate to a molecular memory of the parental cell microenvironment and is required for accurate division [87]. 
Integrins are also important for mitosis, particularly for correct orientation of the mitotic spindle [88-91]. Recent work suggests that the IAC components lost at cell rounding relocate at the lateral regions of the cell cortex where they co-localise with active $\beta 1$ integrin [92]. This association was ligand-independent but forcedependent, with the force generated by integrin-anchored retraction fibres. Although inconsistent with a role for ligand-dependent anchorage in controlling the division axis, it is has been proposed that the formation of this lateral cortical mechanosensory complex determines orientation of the mitotic spindle irrespective of cell microenvironment [92].

\section{Energy and metabolism}

In a teleological sense, it is plausible that signal transduction via IACs controls all cellular functions that need to respond to changes in the extracellular environment. Energy regulation has little historical precedent, but current interest in the tumour microenvironment has raised awareness [93]. Ontological analysis has confirmed the presence of metabolism-related proteins in the proteome of IACs [74,94], one of which is the key metabolic sensor AMPK. AMPK is activated in response to energy insufficiency and drives cell surface changes leading to enhanced nutrient uptake. Pharmacological activation of AMPK reduced expression of receptors associated with adhesion, including $\beta 1$ integrin, possibly to conserve energy expended during migration [95]. Conversely, inhibition of AMPK upregulated the expression of tensins, which bind directly to, and activate, integrins at fibrillar adhesions [96]. Tensins have been implicated previously in Arf4-dependent integrin turnover at fibrillar adhesions [97], where endocytosis of integrins and ECM was required for recruitment and activation of mTOR.

CAIX, a hypoxia-induced carbonic anhydrase upregulated in cancer cells, is an additional metabolism-related component of IACs. Analysis of the CAIX interactome by BiolD under hypoxic conditions identified integrins, CD98 (also an adhesome component) and MMP14 co-located in pseudopodia [98]. MMP14 was also colocalised with Tks5 and cortactin in invadopodia. While not reported to be part of the adhesome, the metabolic pathway co-activator PGC-1a is part of a transcriptional program that down-regulates the expression of adhesion molecules, including integrins, via TCF4 transcription factor inactivation [99]. Conversely, downregulation of PGC-1a increased expression of integrins and FAK [100]. Together, these findings are suggestive of a co-ordination between ECM turnover and energy metabolism.

\section{Outlook}

Our understanding of the composition and structure of IACs, and the mechanisms by which signalling via IACs links to cell fate decisions, has improved markedly over the past decade, and the most significant contributions over the past two years have been reviewed above. In the near future, the application of techniques such as proximity biotinylation, in conjunction with mass spectrometry, will enable networks 
to be built that will complement current models generated from IACs in 2D culture. These studies will provide a means to annotate the adhesome with spatial information, as well as enable investigations of IAC composition in 3D models and in vivo. Improvements in microscopy techniques will also drive investigations of the substructure of IACs, together with analyses of the dynamic changes in location, conformation and post-translational modification of components during signal relaying. Finally, multidisciplinary approaches will continue to link these membraneproximal events to the plethora of functions controlled by adhesion.

\section{Acknowledgements}

We thank Adam Byron (IGMM, University of Edinburgh) and Ed Horton (BRIC, University of Copenhagen, Denmark) for discussions about the uses of the meta adhesome. This work was supported by Cancer Research UK (grant C13329/A21671 to M.J.H.).

\section{Figure legend}

Figure 1. Signal relaying via the consensus adhesome. A schematic representation of proteins most commonly found in IACs [10]. The diagram shows the interactions between adhesome proteins. Interactions with the highest confidence, based on the literature, have greater thickness. Proteins with a thick black node border are members of the literature-curated adhesome protein. Recent evidence suggests the left half of the network transduces signals that regulate phosphorylation and small GTPases [21,28], while the right half is primarily responsible for mechanosensitive connections to actin filaments [45]. Together, these outputs are integrated to influence many aspects of cell phenotype.

\section{References}

1. Cukierman E, Pankov R, Stevens DR, Yamada KM: Taking cell-matrix adhesions to the third dimension. Science 2001, 294:1708-1712.

2. Geiger B, Bershadsky A, Pankov R, Yamada KM: Transmembrane crosstalk between the extracellular matrix--cytoskeleton crosstalk. Nat Rev Mol Cell Biol 2001, 2:793-805.

3. Elkhatib N, Bresteau E, Baschieri F, Rioja AL, van Niel G, Vassilopoulos S, Montagnac G: Tubular clathrin/AP-2 lattices pinch collagen fibers to support 3D cell migration. Science 2017, 356.

4. Grove J, Metcalf DJ, Knight AE, Wavre-Shapton ST, Sun T, Protonotarios ED, Griffin LD, Lippincott-Schwartz J, Marsh M: Flat clathrin lattices: stable features of the plasma membrane. Mol Biol Cell 2014, 25:3581-3594.

5. Leyton-Puig D, Isogai T, Argenzio E, van den Broek B, Klarenbeek J, Janssen H, Jalink K, Innocenti M: Flat clathrin lattices are dynamic actin-controlled hubs 
for clathrin-mediated endocytosis and signalling of specific receptors. Nat Commun 2017, 8:16068.

6. Lock JG, Jones MC, Askari, Gong X, Oddone A, Olofsson H, Goransson S, Lakadamyali M, Humphries MJ, Stromblad S: Reticular adhesions: A new class of adhesion complex that mediates cell-matrix attachment during mitosis. Nature Cell Biology 2018, (in press).

7. Humphries JD, Byron A, Bass MD, Craig SE, Pinney JW, Knight D, Humphries MJ: Proteomic analysis of integrin-associated complexes identifies RCC2 as a dual regulator of Rac1 and Arf6. Sci Signal 2009, 2:ra51.

8. Kuo JC, Han X, Hsiao CT, Yates JR, 3rd, Waterman CM: Analysis of the myosin-IIresponsive focal adhesion proteome reveals a role for beta-Pix in negative regulation of focal adhesion maturation. Nat Cell Biol 2011, 13:383-393.

9. Schiller HB, Friedel CC, Boulegue C, Fassler R: Quantitative proteomics of the integrin adhesome show a myosin II-dependent recruitment of LIM domain proteins. EMBO Rep 2011, 12:259-266.

10. Horton ER, Byron A, Askari JA, Ng DHJ, Millon-Fremillon A, Robertson J, Koper EJ, Paul NR, Warwood S, Knight D, et al.: Definition of a consensus integrin adhesome and its dynamics during adhesion complex assembly and disassembly. Nat Cell Biol 2015, 17:1577-1587.

By merging seven mass spectrometry datasets, a consensus integrin adhesome of 60 proteins is defined that represents the core machinery of fibronectin-induced IACs. In addition, a meta-adhesome of more than 2400 proteins is defined, highlighting the complexity at IACs. Furthermore, examination of IAC proteomes during assembly and disassembly revealed differential dynamics of individual components.

11. Winograd-Katz SE, Fassler R, Geiger B, Legate KR: The integrin adhesome: from genes and proteins to human disease. Nat Rev Mol Cell Biol 2014, 15:273288.

12. Horton ER, Humphries JD, James J, Jones MC, Askari JA, Humphries MJ: The integrin adhesome network at a glance. J Cell Sci 2016, 129:4159-4163.

13. Fokkelman M, Balcioglu HE, Klip JE, Yan K, Verbeek FJ, Danen EH, van de Water B: Cellular adhesome screen identifies critical modulators of focal adhesion dynamics, cellular traction forces and cell migration behaviour. Sci Rep 2016, 6:31707.

14. Sarhan AR, Patel TR, Cowell AR, Tomlinson MG, Hellberg C, Heath JK, Cunningham DL, Hotchin NA: LAR protein tyrosine phosphatase regulates focal adhesions through CDK1. J Cell Sci 2016, 129:2962-2971.

15. Hehenberger E, Tikhonenkov DV, Kolisko M, Del Campo J, Esaulov AS, Mylnikov AP, Keeling PJ: Novel Predators Reshape Holozoan Phylogeny and Reveal the Presence of a Two-Component Signaling System in the Ancestor of Animals. Curr Biol 2017, 27:2043-2050.e2046.

16. Mekhdjian AH, Kai F, Rubashkin MG, Prahl LS, Przybyla LM, McGregor AL, Bell ES, Barnes JM, DuFort CC, Ou G, et al.: Integrin-mediated traction force enhances paxillin molecular associations and adhesion dynamics that increase the invasiveness of tumor cells into a three-dimensional extracellular matrix. Mol Biol Cell 2017, 28:1467-1488. 
17. Rogg M, Yasuda-Yamahara M, Abed A, Dinse P, Helmstadter M, Conzelmann AC, Frimmel J, Sellung D, Biniossek ML, Kretz O, et al.: The WD40-domain containing protein CORO2B is specifically enriched in glomerular podocytes and regulates the ventral actin cytoskeleton. Sci Rep 2017, 7:15910.

18. Schell C, Rogg M, Suhm M, Helmstadter M, Sellung D, Yasuda-Yamahara M, Kretz O, Kuttner V, Suleiman H, Kollipara L, et al.: The FERM protein EPB41L5 regulates actomyosin contractility and focal adhesion formation to maintain the kidney filtration barrier. Proc Natl Acad Sci U S A 2017, 114:E4621-e4630.

19. van Aalderen MC, van den Biggelaar M, Remmerswaal EBM, van Alphen FPJ, Meijer AB, Ten Berge IJM, van Lier RAW: Label-free Analysis of CD8(+) T Cell Subset Proteomes Supports a Progressive Differentiation Model of HumanVirus-Specific T Cells. Cell Rep 2017, 19:1068-1079.

20. Dong JM, Tay FP, Swa HL, Gunaratne J, Leung T, Burke B, Manser E: Proximity biotinylation provides insight into the molecular composition of focal adhesions at the nanometer scale. Sci Signal 2016, 9:rs4.

This paper examines paxillin and kindlin-2 proximal proteins using proximitydependent labelling (BiolD). This technique provides information on interactions within IACs that is complementary to that obtained by IAC isolation. A number of established adhesome components were identified in the study, together with novel candidates, including Kank2.

21. Horton ER, Humphries JD, Stutchbury B, Jacquemet G, Ballestrem C, Barry ST, Humphries MJ: Modulation of FAK and Src adhesion signaling occurs independently of adhesion complex composition. J Cell Biol 2016, 212:349364.

This paper demonstrates that inhibition of FAK and Src kinase signalling blocks cell migration and proliferation without significantly altering the composition of the major components of the integrin adhesome. Using FRAP, the authors propose a model by which adhesion signalling can be regulated by adhesion complex dynamics and signals relayed independently of core composition.

22. Schoenherr C, Frame MC, Byron A: Trafficking of Adhesion and Growth Factor Receptors and their Effector Kinases. Annual Reviews Cell and Developmental Biology 2018.

23. Atkinson SJ, Gontarczyk AM, Alghamdi AA, Ellison TS, Johnson RT, Fowler WJ, Kirkup BM, Silva BC, Harry BE, Schneider JG, et al.: The beta3-integrin endothelial adhesome regulates microtubule-dependent cell migration. EMBO Rep 2018.

24. Bouchet BP, Gough RE, Ammon YC, van de Willige D, Post H, Jacquemet $G$, Altelaar AM, Heck AJ, Goult BT, Akhmanova A: Talin-KANK1 interaction controls the recruitment of cortical microtubule stabilizing complexes to focal adhesions. Elife 2016, 5.

This paper establishes a central role for Kank1 in linking IACs and microtubule dynamics through a direct interaction with talin. The authors provide structural evidence for sites of interaction between Kank1 and talin, which mediate recruitment of Kank1 to the periphery of IACs, initiating the formation of cortical microtubule stabilising complexes. 
25. Sun Z, Tseng HY, Tan S, Senger F, Kurzawa L, Dedden D, Mizuno N, Wasik AA, Thery M, Dunn AR, et al.: Kank2 activates talin, reduces force transduction across integrins and induces central adhesion formation. Nat Cell Biol 2016, 18:941-953.

26. Li H, Deng Y, Sun K, Yang H, Liu J, Wang M, Zhang Z, Lin J, Wu C, Wei Z, et al.: Structural basis of kindlin-mediated integrin recognition and activation. Proc Natl Acad Sci U S A 2017, 114:9349-9354.

27. Bledzka K, Bialkowska K, Sossey-Alaoui K, Vaynberg J, Pluskota E, Qin J, Plow EF: Kindlin-2 directly binds actin and regulates integrin outside-in signaling. J Cell Biol 2016, 213:97-108.

28. Bottcher RT, Veelders M, Rombaut P, Faix J, Theodosiou M, Stradal TE, Rottner K, Zent R, Herzog F, Fassler R: Kindlin-2 recruits paxillin and Arp2/3 to promote membrane protrusions during initial cell spreading. J Cell Biol 2017, 216:3785-3798.

29. Harizanova J, Fermin Y, Malik-Sheriff RS, Wieczorek J, Ickstadt K, Grecco HE, Zamir E: Highly Multiplexed Imaging Uncovers Changes in Compositional Noise within Assembling Focal Adhesions. PLoS One 2016, 11:e0160591.

30. Nader GP, Ezratty EJ, Gundersen GG: FAK, talin and PIPKIgamma regulate endocytosed integrin activation to polarize focal adhesion assembly. Nat Cell Biol 2016, 18:491-503.

31. Dupont S, Morsut L, Aragona M, Enzo E, Giulitti S, Cordenonsi M, Zanconato F, Le Digabel J, Forcato M, Bicciato S, et al.: Role of YAP/TAZ in mechanotransduction. Nature 2011, 474:179-183.

32. Engler AJ, Sen S, Sweeney HL, Discher DE: Matrix elasticity directs stem cell lineage specification. Cell 2006, 126:677-689.

33. Janmey PA, Wells RG, Assoian RK, McCulloch CA: From tissue mechanics to transcription factors. Differentiation 2013, 86:112-120.

34. Chin L, Xia Y, Discher DE, Janmey PA: Mechanotransduction in cancer. Curr Opin Chem Eng 2016, 11:77-84.

35. Tschumperlin DJ, Ligresti G, Hilscher MB, Shah VH: Mechanosensing and fibrosis. J Clin Invest 2018, 128:74-84.

36. Gauthier NC, Roca-Cusachs P: Mechanosensing at integrin-mediated cell-matrix adhesions: from molecular to integrated mechanisms. Curr Opin Cell Biol 2018, 50:20-26.

37. Han MK, de Rooij J: Converging and Unique Mechanisms of Mechanotransduction at Adhesion Sites. Trends Cell Biol 2016, 26:612-623.

38. Sun Z, Guo SS, Fassler R: Integrin-mediated mechanotransduction. J Cell Biol 2016, 215:445-456.

39. Elosegui-Artola A, Trepat X, Roca-Cusachs P: Control of Mechanotransduction by Molecular Clutch Dynamics. Trends Cell Biol 2018, 28:356-367.

40. Oria R, Wiegand T, Escribano J, Elosegui-Artola A, Uriarte JJ, Moreno-Pulido C, Platzman I, Delcanale P, Albertazzi L, Navajas D, et al.: Force loading explains spatial sensing of ligands by cells. Nature 2017, 552:219-224.

This paper dissects the contributions of ECM nanoscale ligand spacing and substrate rigidity on the ability of cells to form cell-matrix adhesions. The authors propose that cell behaviour can be explained by a molecular force loading model that incorporates rigidity, ligand distribution and contractility effects. 
41. Bennett M, Cantini M, Reboud J, Cooper JM, Roca-Cusachs P, Salmeron-Sanchez M: Molecular clutch drives cell response to surface viscosity. Proc Natl Acad Sci U S A 2018, 115:1192-1197.

42. Pontes B, Monzo P, Gole L, Le Roux AL, Kosmalska AJ, Tam ZY, Luo W, Kan S, Viasnoff $\mathrm{V}$, Roca-Cusachs $\mathrm{P}$, et al.: Membrane tension controls adhesion positioning at the leading edge of cells. J Cell Biol 2017, 216:2959-2977.

43. Ray A, Lee O, Win Z, Edwards RM, Alford PW, Kim DH, Provenzano PP:

Anisotropic forces from spatially constrained focal adhesions mediate contact guidance directed cell migration. Nat Commun 2017, 8:14923.

44. Horton ER, Astudillo P, Humphries MJ, Humphries JD: Mechanosensitivity of integrin adhesion complexes: role of the consensus adhesome. Exp Cell Res 2016, 343:7-13.

45. Stutchbury B, Atherton P, Tsang R, Wang DY, Ballestrem C: Distinct focal adhesion protein modules control different aspects of mechanotransduction. J Cell Sci 2017, 130:1612-1624.

46. Spiess M, Hernandez-Varas P, Oddone A, Olofsson H, Blom H, Waithe D, Lock JG, Lakadamyali $\mathrm{M}$, Stromblad S: Active and inactive beta1 integrins segregate into distinct nanoclusters in focal adhesions. J Cell Biol 2018, 217:1929-1940.

47. Malik-Sheriff RS, Imtiaz S, Grecco HE, Zamir E: Diverse patterns of molecular changes in the mechano-responsiveness of focal adhesions. Sci Rep 2018, 8:2187.

48. Xu L, Braun LJ, Ronnlund D, Widengren J, Aspenstrom P, Gad AKB: Nanoscale localization of proteins within focal adhesions indicates discrete functional assemblies with selective force-dependence. Febs j 2018, 285:1635-1652.

49. Bulgakova NA, Wellmann J, Brown NH: Diverse integrin adhesion stoichiometries caused by varied actomyosin activity. Open Biol 2017, 7.

50. Kong F, Garcia AJ, Mould AP, Humphries MJ, Zhu C: Demonstration of catch bonds between an integrin and its ligand. J Cell Biol 2009, 185:1275-1284.

51. Huang DL, Bax NA, Buckley CD, Weis WI, Dunn AR: Vinculin forms a directionally asymmetric catch bond with F-actin. Science 2017, 357:703-706.

52. Nordenfelt P, Moore TI, Mehta SB, Kalappurakkal JM, Swaminathan V, Koga N, Lambert TJ, Baker D, Waters JC, Oldenbourg R, et al.: Direction of actin flow dictates integrin LFA-1 orientation during leukocyte migration. Nat Commun 2017, 8:2047.

53. Swaminathan V, Kalappurakkal JM, Mehta SB, Nordenfelt P, Moore TI, Koga N, Baker DA, Oldenbourg R, Tani T, Mayor S, et al.: Actin retrograde flow actively aligns and orients ligand-engaged integrins in focal adhesions. Proc Natl Acad Sci U S A 2017, 114:10648-10653.

54. Li J, Springer TA: Integrin extension enables ultrasensitive regulation by cytoskeletal force. Proc Natl Acad Sci U S A 2017, 114:4685-4690.

55. Gaub BM, Muller DJ: Mechanical Stimulation of Piezo1 Receptors Depends on Extracellular Matrix Proteins and Directionality of Force. Nano Lett 2017, 17:2064-2072.

56. Gudipaty SA, Lindblom J, Loftus PD, Redd MJ, Edes K, Davey CF, Krishnegowda V, Rosenblatt J: Mechanical stretch triggers rapid epithelial cell division through Piezo1. Nature 2017, 543:118-121. 
From observations that cells divide in sparsely populated areas of an epithelium and by experimentally stretching epithelia, this paper uncovered a link from cell density to activation of cell division via the mechanosensitive transmembrane channel Piezo1, calcium signalling and ERK1/2 activation.

57. Jacquemet G, Baghirov H, Georgiadou M, Sihto H, Peuhu E, Cettour-Janet P, He T, Perala $\mathrm{M}$, Kronqvist $\mathrm{P}$, Joensuu $\mathrm{H}$, et al.: L-type calcium channels regulate filopodia stability and cancer cell invasion downstream of integrin signalling. Nat Commun 2016, 7:13297.

58. Carisey A, Tsang R, Greiner AM, Nijenhuis N, Heath N, Nazgiewicz A, Kemkemer R, Derby B, Spatz J, Ballestrem C: Vinculin regulates the recruitment and release of core focal adhesion proteins in a force-dependent manner. Curr Biol 2013, 23:271-281.

59. Cohen DM, Kutscher B, Chen H, Murphy DB, Craig SW: A conformational switch in vinculin drives formation and dynamics of a talin-vinculin complex at focal adhesions. J Biol Chem 2006, 281:16006-16015.

60. del Rio A, Perez-Jimenez R, Liu R, Roca-Cusachs P, Fernandez JM, Sheetz MP: Stretching single talin rod molecules activates vinculin binding. Science 2009, 323:638-641.

61. Humphries JD, Wang P, Streuli C, Geiger B, Humphries MJ, Ballestrem C: Vinculin controls focal adhesion formation by direct interactions with talin and actin. J Cell Biol 2007, 179:1043-1057.

62. Izard T, Vonrhein C: Structural basis for amplifying vinculin activation by talin. J Biol Chem 2004, 279:27667-27678.

63. Sawada Y, Tamada M, Dubin-Thaler BJ, Cherniavskaya O, Sakai R, Tanaka S, Sheetz MP: Force sensing by mechanical extension of the Src family kinase substrate p130Cas. Cell 2006, 127:1015-1026.

64. Kumar A, Ouyang M, Van den Dries K, McGhee EJ, Tanaka K, Anderson MD, Groisman A, Goult BT, Anderson KI, Schwartz MA: Talin tension sensor reveals novel features of focal adhesion force transmission and mechanosensitivity. J Cell Biol 2016, 213:371-383.

This paper described the use of a talin tension FRET sensor to show variable forces acting upon talin, unlike vinculin, depend on substrate stiffness and peripheral versus central adhesion complex localisation. The forces on talin were differentially regulated by the $A B S 2$ and $A B S 3$ domains of vinculin.

65. Ringer P, Weissl A, Cost AL, Freikamp A, Sabass B, Mehlich A, Tramier M, Rief M, Grashoff C: Multiplexing molecular tension sensors reveals piconewton force gradient across talin-1. Nat Methods 2017, 14:1090-1096.

66. Chorev DS, Volberg T, Livne A, Eisenstein M, Martins B, Kam Z, Jockusch BM, Medalia O, Sharon M, Geiger B: Conformational states during vinculin unlocking differentially regulate focal adhesion properties. Sci Rep 2018, 8:2693.

67. Elosegui-Artola A, Andreu I, Beedle AEM, Lezamiz A, Uroz M, Kosmalska AJ, Oria R, Kechagia JZ, Rico-Lastres P, Le Roux AL, et al.: Force Triggers YAP Nuclear Entry by Regulating Transport across Nuclear Pores. Cell 2017, 171:13971410.e1314.

This paper reported further insights into YAP nuclear translocation through a mechanosensitive pathway from the stiff ECM to the nucleus via the 
cytoskeleton, talin and IACs. The overall effect is an increase in nuclear YAP import via nuclear flattening and stretching of nuclear pores.

68. Shiu JY, Aires L, Lin Z, Vogel V: Nanopillar force measurements reveal actin-capmediated YAP mechanotransduction. Nat Cell Biol 2018, 20:262-271.

69. Guo L, Cai T, Chen K, Wang R, Wang J, Cui C, Yuan J, Zhang K, Liu Z, Deng Y, et al.: Kindlin-2 regulates mesenchymal stem cell differentiation through control of YAP1/TAZ. J Cell Biol 2018, 217:1431-1451.

70. Lachowski D, Cortes E, Robinson B, Rice A, Rombouts K, Del Rio Hernandez AE: FAK controls the mechanical activation of YAP, a transcriptional regulator required for durotaxis. Faseb j 2018, 32:1099-1107.

71. Sero JE, Bakal C: Multiparametric Analysis of Cell Shape Demonstrates that beta-PIX Directly Couples YAP Activation to Extracellular Matrix Adhesion. Cell Syst 2017, 4:84-96.e86.

72. Caridi CP, D'Agostino C, Ryu T, Zapotoczny G, Delabaere L, Li X, Khodaverdian VY, Amaral N, Lin E, Rau AR, et al.: Nuclear F-actin and myosins drive relocalization of heterochromatic breaks. Nature 2018.

73. Schrank BR, Aparicio T, Li Y, Chang W, Chait BT, Gundersen GG, Gottesman ME, Gautier J: Nuclear ARP2/3 drives DNA break clustering for homologydirected repair. Nature 2018.

74. Geiger T, Zaidel-Bar R: Opening the floodgates: proteomics and the integrin adhesome. Curr Opin Cell Biol 2012, 24:562-568.

75. Stoker M, O'Neill C, Berryman S, Waxman V: Anchorage and growth regulation in normal and virus-transformed cells. Int J Cancer 1968, 3:683-693.

76. Assoian RK, Schwartz MA: Coordinate signaling by integrins and receptor tyrosine kinases in the regulation of G1 phase cell-cycle progression. Curr Opin Genet Dev 2001, 11:48-53.

77. Frisch SM, Ruoslahti E: Integrins and anoikis. Curr Opin Cell Biol 1997, 9:701-706.

78. Enserink JM, Kolodner RD: An overview of Cdk1-controlled targets and processes. Cell Div 2010, 5:11.

79. Holt LJ, Tuch BB, Villen J, Johnson AD, Gygi SP, Morgan DO: Global analysis of Cdk1 substrate phosphorylation sites provides insights into evolution. Science 2009, 325:1682-1686.

80. Robertson J, Jacquemet G, Byron A, Jones MC, Warwood S, Selley JN, Knight D, Humphries JD, Humphries MJ: Defining the phospho-adhesome through the phosphoproteomic analysis of integrin signalling. Nat Commun 2015, 6:6265.

81. Jones MC, Askari JA, Humphries JD, Humphries MJ: Cell adhesion is regulated by CDK1 during the cell cycle. J Cell Biol 2018.

This paper reveals a link between the cell cycle and cell adhesion. The authors present data to show that remodelling of IACs and actin begins in G2 and that rounding prior to mitosis is triggered by inhibition of CDK1 by Wee1. In addition, the increase in IAC area observed in $\mathrm{S}$ is dependent on the phosphorylation of the formin FMNL2 by CDK1.

82. Uroz M, Wistorf S, Serra-Picamal X, Conte V, Sales-Pardo M, Roca-Cusachs P, Guimera R, Trepat X: Regulation of cell cycle progression by cell-cell and cell-matrix forces. Nat Cell Biol 2018, 20:646-654. 
This paper uncovers an association between evolution of cellular forces and progression of the cell cycle. Cellular traction forces in an epithelial monolayer are found to affect various aspects of the cell cycle including duration, G1-S progression and mitotic rounding. These findings confirm a role for cell mechanics in the regulation of cell proliferation.

83. Vianay B, Senger F, Alamos S, Anjur-Dietrich M, Bearce E, Cheeseman B, Lee L, Thery M: Variation in traction forces during cell cycle progression. Biol Cell 2018, 110:91-96.

84. Ingallina E, Sorrentino G, Bertolio R, Lisek K, Zannini A, Azzolin L, Severino LU, Scaini D, Mano M, Mantovani F, et al.: Mechanical cues control mutant p53 stability through a mevalonate-RhoA axis. Nat Cell Biol 2018, 20:28-35.

85. Ahmed KM, Pandita RK, Singh DK, Hunt CR, Pandita TK: beta1-Integrin Impacts Rad51 Stability and DNA Double-Strand Break Repair by Homologous Recombination. Mol Cell Biol 2018, 38.

86. Elacqua JJ, McGregor AL, Lammerding J: Automated analysis of cell migration and nuclear envelope rupture in confined environments. PLoS One 2018, 13:e0195664.

87. Dix CL, Matthews HK, Uroz M, McLaren S, Wolf L, Heatley N, Win Z, Almada P, Henriques R, Boutros M, et al.: The Role of Mitotic Cell-Substrate Adhesion Re-modeling in Animal Cell Division. Dev Cell 2018, 45:132-145.e133.

88. Reverte CG, Benware A, Jones CW, LaFlamme SE: Perturbing integrin function inhibits microtubule growth from centrosomes, spindle assembly, and cytokinesis. J Cell Biol 2006, 174:491-497.

89. Taneja N, Fenix AM, Rathbun L, Millis BA, Tyska MJ, Hehnly H, Burnette DT: Focal adhesions control cleavage furrow shape and spindle tilt during mitosis. Sci Rep 2016, 6:29846.

90. Thery M, Racine V, Pepin A, Piel M, Chen Y, Sibarita JB, Bornens M: The extracellular matrix guides the orientation of the cell division axis. Nat Cell Biol 2005, 7:947-953.

91. Toyoshima F, Nishida E: Integrin-mediated adhesion orients the spindle parallel to the substratum in an EB1- and myosin X-dependent manner. Embo j 2007, 26:1487-1498.

92. Petridou NI, Skourides PA: A ligand-independent integrin beta1 mechanosensory complex guides spindle orientation. Nat Commun 2016, 7:10899.

93. Ata R, Antonescu CN: Integrins and Cell Metabolism: An Intimate Relationship Impacting Cancer. Int J Mol Sci 2017, 18.

94. Byron A, Humphries JD, Humphries MJ: Alternative cellular roles for proteins identified using proteomics. J Proteomics 2012, 75:4184-4185.

95. Ross E, Ata R, Thavarajah T, Medvedev S, Bowden P, Marshall JG, Antonescu CN: AMP-Activated Protein Kinase Regulates the Cell Surface Proteome and Integrin Membrane Traffic. PLoS One 2015, 10:e0128013.

96. Georgiadou M, Lilja J, Jacquemet G, Guzman C, Rafaeva M, Alibert C, Yan Y, Sahgal P, Lerche M, Manneville JB, et al.: AMPK negatively regulates tensindependent integrin activity. J Cell Biol 2017, 216:1107-1121.

This paper presents data implicating the prominent metabolic sensor AMPK in mediating integrin activation, fibronectin fibrillogenesis and potentially 
fibrosis. Inhibition of AMPK increased integrin ?1 activity through inducing the expression of integrin-binding tensins. As a consequence, AMPK promoted cell adhesion, mechanotransduction, and ECM assembly.

97. Rainero E, Howe JD, Caswell PT, Jamieson NB, Anderson K, Critchley DR, Machesky L, Norman JC: Ligand-Occupied Integrin Internalization Links Nutrient Signaling to Invasive Migration. Cell Rep 2015.

98. Swayampakula M, McDonald PC, Vallejo M, Coyaud E, Chafe SC, Westerback A, Venkateswaran G, Shankar J, Gao G, Laurent EMN, et al.: The interactome of metabolic enzyme carbonic anhydrase IX reveals novel roles in tumor cell migration and invadopodia/MMP14-mediated invasion. Oncogene 2017, 36:6244-6261.

99. Minsky N, Roeder RG: Inhibition of Adhesion Molecule Gene Expression and Cell Adhesion by the Metabolic Regulator PGC-1alpha. PLoS One 2016, 11:e0165598.

100. Luo C, Lim JH, Lee Y, Granter SR, Thomas A, Vazquez F, Widlund HR, Puigserver $P$ : A PGC1alpha-mediated transcriptional axis suppresses melanoma metastasis. Nature 2016, 537:422-426. 


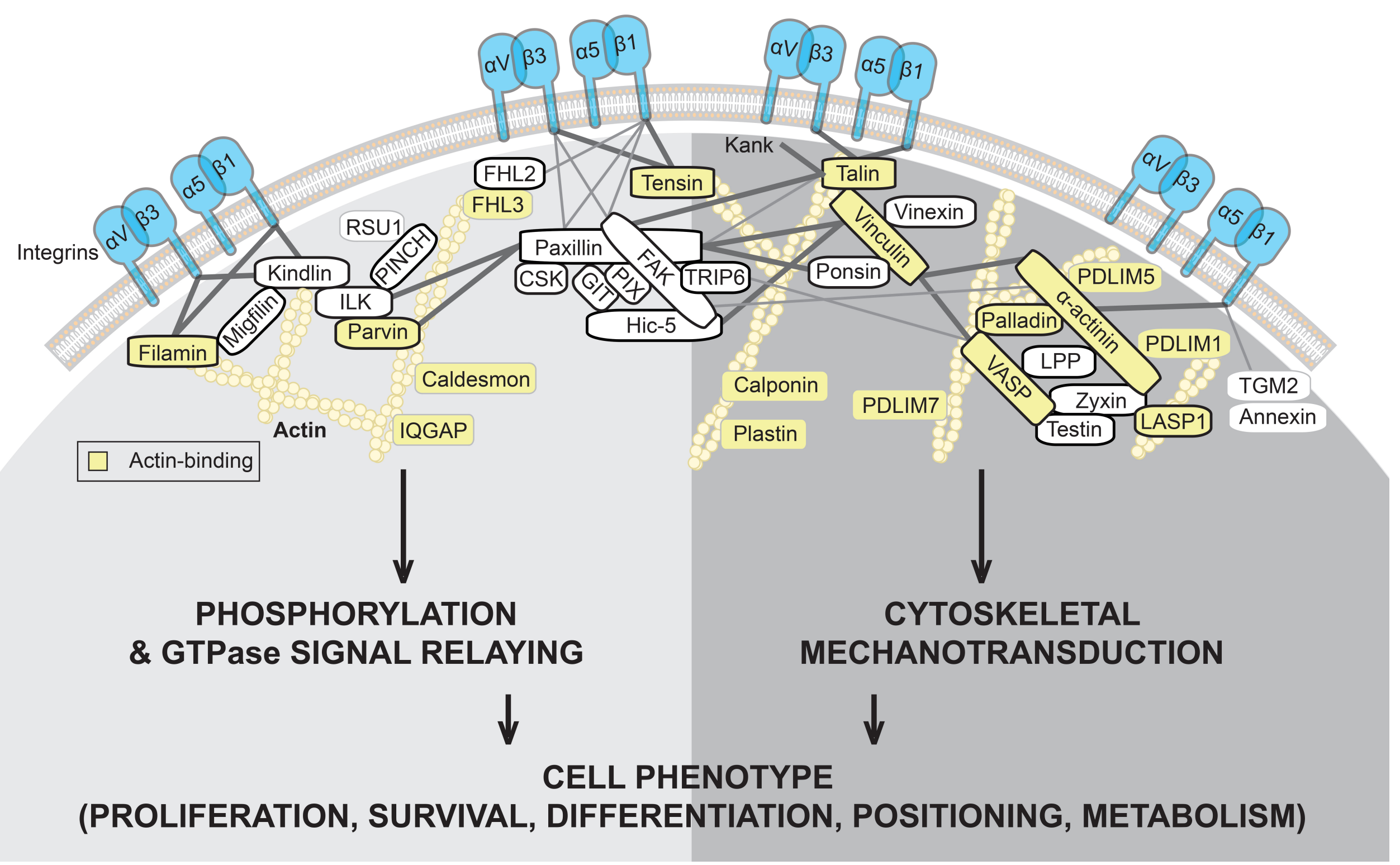

